\title{
Spinoza, Arch-Father of the Material Religion Approach and New Materialisms
}

\section{Pooyan Tamimi Arab}

To cite this article: Pooyan Tamimi Arab (2019) Spinoza, Arch-Father of the Material Religion Approach and New Materialisms, Material Religion, 15:5, 624-626, DOI: 10.1080/17432200.2019.1666583

To link to this article: https://doi.org/10.1080/17432200.2019.1666583

曲 Published online: 18 Oct 2019.

Submit your article to this journal $\pi$

III Article views: 44

Q View related articles $₫$

View Crossmark data $\asymp$ 


\section{spinoza, arch-father of the material religion approach and new materialisms}

\author{
pooyan tamimi arab
}

Theories that inform the material religion approach and contributions to the field of so-called new materialisms are derived from older scientific endeavors to study religion as a human, historical, or even natural phenomenon. They echo the Enlightenment and nineteenth century materialist, historicist, and political critiques of religion, which led to a perspective that methodologically excludes the idea of transcendence. Simultaneously, colonial empires facilitated the anthropological examination of diverse peoples' rituals and experiences, of something that they may call God, spirits, the sacred, or the transcendent. Given this enormous backdrop to what may appear as two recent and related approaches, what we are engaged in is, in fact, a process of constant reinterpretation of past materialisms from contemporary standpoints and in a dialectic with new empirical studies. This is already clearly the case in theory-driven works by David Chidester (1992, 2018), but also in recent reflections by Birgit Meyer (2016) on the material religion approach's resonance with scholars whom we should "re-member" through critical reevaluation, such as Feuerbach, Durkheim, Marett, or Cassirer.

I am particularly interested in the genealogical reconstruction of the material religion approach, because it leads to rereading philosophers through a material religion lens. What did our philosophical ancestors write on a theoretical level about material religion, and how did they rely on knowledge of practical religious matters, about buildings, foods, and diverse sartorial practices? Similarities and discrepancies between the current material religion approach and new materialisms can also be clarified by looking at different readings of past thinkers. For specifically this comparison, I believe that Spinoza is a key figure.

Pooyan Tamimi Arab is assistant professor of Religious Studies at Utrecht University. He is author of Amplifying Islam in the European soundscape (Bloomsbury, 2017). In his new research project Pictures That Divide he focuses on visual culture, Islam, and diversity in the Netherlands. p.tamimiarab@uu.nl

Material Religion volume 15, issue 5, pp. 624-626 DOI: 10.1080/17432200.2019.1666583

Check for updates

๑ 2019 Informa UK Limited, trading as Taylor \& Francis Group
Contributors to the material religion approach rarely cite Spinoza, but they do build on the socalled affective turn in the humanities and the social sciences, which safeguarded the theoretical significance of the sensing body against a too reductive focus on texts and beliefs alone, and allowed a critical stance towards the notorious Protestant bias in studies of religion. Spinoza's influence is often acknowledged indirectly in references to Deleuze (1968[1992]; 1970[1988]) and Massumi (2002), in works by anthropologists, religious studies scholars, art historians, and political theorists. It is somewhat surprising that Spinoza himself is named only twice in the fifteen volumes of the journal Material Religion, once by Guthrie (2007), who places the early modern philosopher in a lineage extending to Feuerbach and Freud, and once by Espírito Santo (2019), via Deleuze.

I agree with Sally Promey (2014), who states in the introduction to her edited volume Sensational Religion: Sensory Cultures in Material Practice that the intricacies of philosophers' such as Spinoza should not be forgotten by those adopting a material religion approach, who may otherwise succumb to an oversimplified history of the senses in western modernity. Promey refers to the fact that Spinoza's Ethics disrupts easy schemas of Western thought as separating mind from body. And I want to add that the Political-Theological Treatise reveals familiar thoughts about the power of the imagination. For example, in a fascinating passage that foretells Durkheim, Spinoza leaves no doubt about the fact that ultimately "nothing is sacred, profane, or impure, absolutely and independently of the mind but only in relation to the mind" (TTP, ch. 12). Since Spinoza conceives of the mind as equal to the body - the famous "parallelism," as coined by Leibniz - the mind's imagination can be manipulated through diverse corporeal techniques and material media that are essential to generate religious experiences and to construct shared religious identities (Tamimi Arab forthcoming). He envisions these aesthetically formed identities as essential to his ideal state, which must actively define what counts as "religion" by regulating material manifestations. This leads Spinoza to write about practices such as Jewish circumcision or on what he deemed to be the desired and tolerable limits of religious minorities' architectural presence.

New materialisms scholars, by contrast, cite and discuss Spinoza extensively, but do not focus on material religion and the practical, historically situated problematics of Spinoza's theological-realpolitik. In books such as Vibrant Matter (Bennett 2010), The Posthuman (Braidotti 2013), and Pantheologies: Gods, Worlds, Monsters (Rubenstein 2018), these and other scholars rather exhibit a deep interest in Spinoza's cosmology. Special attention is paid 
to the subject understood as the resultant of ever-changing natural forces that can be studied as if, in Spinoza's famous opening words to the third part of the Ethics, "it were a question of lines, planes, and bodies." In such works that build on Spinoza, affects are understood in an anti-essentialist manner as being always in flux. Disassembling well-trodden boundaries between subject and object, and culture and nature, I understand this affective turn towards a complex (entangled) subject as an animalization of the human being. We only need to recall Deleuze's fascination with Spinoza and Bergson's philosophy of life, the latter having been developed in response to the Darwinian revolution (cf. Grosz 2007). This interest in animalization is connected, for instance, to Deleuze's meditations on the paintings of Francis Bacon, about which he wrote The Logic of Sensation (2003[1981]), on violent images of humans as animated, religious, creatures composed of meat, bones, and fluids: "what Bacon's painting constitutes is a zone of indiscernibility or undecidability between man and animal. Man becomes animal, but not without the animal becoming spirit at the same time, the spirit of man, the physical spirit of man" $(2003,21)$. Consequently, new materialisms' critique of an anthropocentric understanding of nature and our place in it does not yield a loss of interest in studying art or religion. This well-taken critique should not be misidentified to be a self-defeating endeavor for scholars interested in the humanities, which are by definition mainly interested in human perspectives. The point is that, as was the case already with Spinoza and later naturalists, that the critique of anthropocentrism changes the ways in which we see human phenomena.

The new materialists' strong - and in my opinion unconvincing - ideas of pantheism and panpsychism also revolve around conflicting interpretations of Spinoza. Peter Bräunlein's critical take on Jane Bennet (this In Conversation), for example, can be further clarified by looking at how she understands Spinoza's concept of conatus - that each thing strives to persevere in its being. In Bennet's reading, all "bodies," which is to say all things in the universe, possess vitality $(2010,2)$. But such an anthropomorphization contradicts the important critique of anthropocentrism, in my view, and goes against the heart of what Spinoza is arguing for in the specific context of the seventeenth century. Spinoza's controversial point is, namely, not that matter is vibrant, but that the vibrant human "spirit" is material, i.e. that the human mind is not superior to the body and cannot be disentangled from it - a perspective from which he set out to define all human affects (Ethics P2 and P3). Admittedly, whether Spinoza himself attributed minds to non-organic objects is an interpretative question that philos- ophers disagree on, depending on what is meant with "mind" in so far that it can be separated from living beings in Spinoza's system.

Moreover, if we turn to the broader field of affect theory, to which scholars of the material religion approach and new materialists relate, we can note that popular anti-essentalist readings of Spinoza's subject in late 20th century France and Italy are continuously debated. For example, Donovan Schaefer $(2015,41)$, taking up new materialists as theoretical interlocutors, comments that "affect in this [Spinozist] sense images bodies as sand castles, granulated conglomerates that are susceptible to radical reformation by the action of multidirectional waves washing over them". Schaefer thinks that radical readers of Spinoza who are critical of biological determinism, then, make the mistake of exaggerating to its complete opposite - not unlike the behaviorists of the 1950s - going from determinism to a "hyperplasticity" in which it seems that in nature anything is possible (Idem., 41, 97). Such a vision aligns well with Rosi Braidotti's ideal of post-human and planetary ethics (2013), which require fundamental transformations in human behavior and on a massive scale. And yet, I see a cleavage between new materialists' appraisal of Spinoza, and his ethics and politics that do not go so far and revolve around the Homo Liber, who is not an endlessly becoming Liber (Schneider 2019). For Spinoza, the human being cannot easily transcend itself, if at all. So, while Spinoza is known for criticizing anthropocentric epistemologies, the significance of the concept of the human in his philosophy should not be underestimated. The human, for Spinoza, entails a subject that is by default delimited, rather than being liberated by religious affects. This is most evident in Spinoza's pessimistic concept of the "multitude," the majority of people who do not live under the guidance of reason, which he thought of as a lasting philosophical problem (Yovel 1989).

In conclusion, by attending to past thinkers such as Spinoza, we will be able to better situate the material religion approach and new materialisms in a common genealogy, make comparisons, and engage with broader critical perspectives on affects, ethics, and politics.

\section{References}

Bennett, Jane. 2010. Vibrant Matter: A Political Ecology of Things. Durham: Duke University Press.

Braidotti, Rosi. 2013. The Posthuman. Cambridge, UK: Polity Press.

Chidester, David. 1992. Word and Light: Seeing, Hearing, and Religious Discourse. Urbana: University of Illinois Press.

Chidester, David. 2018. Religion: Material Dynamics. Oakland: University of California Press. 
Deleuze, Gilles. 1988 [1970]. Spinoza: Practical Philosophy. Translated by Robert Hurley. San Francisco: City Lights Books.

Deleuze, Gilles. 1992 [1968]. Expressionism in Philosophy: Spinoza. Translated by Martin Joughin. New York: Zone Books.

Deleuze, Gilles. 2003 [1981]. Francis Bacon: The Logic of Sensation. Translated by Daniel W. Smith. London: Continuum.

Espírito Santo, Diana. 2019. “The Ontogeny of Dolls: Materiality, Affect, and Self in Afro-Cuban Espiritismo." Material Religion 15 (3): 269-292.

Grosz, Elizabeth. 2007. “Deleuze, Bergson and the Concept of Life." Revue Internationale de Philosophie 241: 287-300.

Guthrie, Stewart. 2007."Bottles Are Men, Glasses Are Women: Religion, Gender, and Secular Objects." Material Religion 7 (1): 14-33.

Massumi, Brian. 2002. Parables for the Virtual: Movement, Affect, Sensation. Durham: Duke University Press.

Meyer, Birgit. 2016. "How to Capture the 'Wow': R.R. Marett's Notion of Awe and the Study of Religion." Journal of the Royal Anthropological Institute 22 (1): 7-26.
Promey, Sally (ed.). 2014. Sensational Religion: Sensory Cultures in Material Practice. New Haven: Yale University Press.

Rubenstein, Mary-Jane. 2018. Pantheologies: Gods, Worlds, Monsters. New York: Columbia University Press.

Schaefer, Donovan. 2015. Religious Affects: Evolution, Animality, and Power. Durham: Duke University Press.

Schneider, Daniel. 2019. "Spinoza on the Conditions of the Human Condition. The Significance of the Concept ' Homo' in Spinoza's Conception of 'Homo Liber." Unpublished Paper Presented at the Second Netherlanders and Israelis Spinoza Seminar at Erasmus University, Rotterdam.

Tamimi Arab, Pooyan. Forthcoming. "Pluriformity and Material Religion in the Political Philosophy of Spinoza." In The Routledge Handbook of Material Religion, edited by S. Brent Plate, Pooyan Tamimi Arab, and Jennifer Hughes. London: Routledge.

Yovel, Yirmiyahu. 1989. Spinoza and Other Heretics: The Marrano of Reason. Princeton: Princeton University Press. 